\title{
Polyphenol mixture of a native Korean variety of Artemisia argyi H. (Seomae mugwort) and its anti-inflammatory effects
}

\author{
SEONG MIN KIM $^{1^{*}}$, SOO JUNG LEE ${ }^{2 *}$, VENU VENKATARAME GOWDA SARALAMMA ${ }^{1}$,

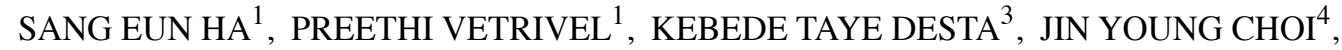 \\ WON SUP LEE ${ }^{5}$, SUNG CHUL SHIN ${ }^{6}$ and GON-SUP KIM ${ }^{1}$
}

${ }^{1}$ Research Institute of Life Science and College of Veterinary Medicine; ${ }^{2}$ Institute of Agriculture and Life Science, Gyeongsang National University, Jinju, Gyeongsang 52828, Republic of Korea; ${ }^{3}$ Department of Chemistry, College of Natural and Computational Sciences, Mekelle University, Mekelle, Tigray National Regional State, Ethiopia; ${ }^{4}$ Department of Chemistry, Gyeongsang National University; ${ }^{5}$ Department of Internal Medicine, Institute of Health Sciences, Gyeongsang National University Hospital and Gyeongsang National University School of Medicine;

${ }^{6}$ Research Institute of Life Science, Gyeongsang National University, Jinju, Gyeongsang 52828, Republic of Korea

Received April 5, 2019; Accepted August 8, 2019

DOI: $10.3892 /$ ijmm.2019.4334

\begin{abstract}
In the present study, a polyphenolic mixture was isolated from Seomae mugwort (SM; a native Korean variety of Artemisia argyi H.) via extraction with aqueous $70 \%$ methanol followed by the elution of ethyl acetate over a silica gel column. Each polyphenolic compound was analyzed using high-performance liquid chromatography coupled with tandem mass spectrometry, and compared with the literature. In addition to the 14 characterized components, one hydroxycinnamate, six flavonoids, and one lignan were reported for the first time, to the best our knowledge, in Artemisia argyi $\mathrm{H}$. The anti-inflammatory properties of SM polyphenols were studied in lipopolysaccharide-treated RAW 264.7 macrophage cells. The SM polyphenols attenuated the activation of macrophages via the inhibition of nitric oxide production, nuclear factor- $\kappa \mathrm{B}$ activation, the mRNA expression of inducible nitric oxide synthase, tumor necrosis factor $\alpha$ and interleukin-1 $\beta$, and the
\end{abstract}

Correspondence to: Professor Gon-Sup Kim, Research Institute of Life Science and College of Veterinary Medicine, Gyeongsang National University, Jinju, Gyeongsang 52828, Republic of Korea E-mail: gonskim@gnu.ac.kr

Professor Won Sup Lee, Department of Internal Medicine, Institute of Health Sciences, Gyeongsang National University Hospital and Gyeongsang National University School of Medicine, Jinju, Gyeongsang 52828, Republic of Korea

E-mail: lwshmo@gnu.ac.kr

*Contributed equally

Key words: Seomae mugwort, Artemisia argyi, polyphenol, flavonoid, liquid chromatography, anti-inflammatory activity phosphorylation of mitogen-activated protein kinase. Our results suggested that SM polyphenols may have therapeutic potential for the treatment of inflammatory-related diseases.

\section{Introduction}

The genus Artemisia argyi H. (A. argyi), a perennial herb that belongs to the Asteraceae family, is ubiquitously distributed in the northern hemisphere (1). The plant has been used for various purposes, such as spring greens, spices, native tea or ornamentation (2). In addition, it has been traditionally used in the Far East to treat or prevent a variety of diseases, which include eczema, diarrhea, inflammation, hemostasis, menstruation-related symptoms and tuberculosis (3). Pharmacological research has demonstrated that $A$. argyi exhibits a variety of biological activities, such as anti-diabetic (4), anti-oxidant (5), anti-cancer (6,7), anti-microbial (8), anti-inflammatory (9), anti-ulcer (10), and anti-allergic (11) activities.

Among a number of components (fatty acid, amino acid, vitamin C, coumarins, glycosides, polyphenols, polyacetylenes, terpenes, sterols, sesquiterpene lactones and essential oils) identified from A. argyi $(12,13)$. Polyphenols usually detected in plants can be classified into two groups of flavonoids and non-flavonoids, and may be notably responsible for various pharmacological activities (14). Polyphenols including flavonoids serve a role as powerful anti-oxidants that are capable of scavenging reactive oxygen species, thereby suppressing the pathogenesis of age-related degenerative diseases, such as diabetes, cardiovascular disease, cancer, and neurodegenerative diseases $(15,16)$. Scientists have been shown great interest in the study of plant flavonoids, as of their potential application in the fields of nutrition and pharmacology, where A. argyi could be an attractive research target (17).

Inflammation is a defensive immune response of the human body that is conferred by the host against harmful stimuli, such 
as foreign pathogens, damaged cells or irritants (18). Prolonged and uncontrolled inflammation hyperactivates macrophage and nuclear factor- $\kappa \mathrm{B}(\mathrm{NF}-\kappa \mathrm{B})$, which up regulates pro-inflammatory mediators, such as inducible nitric oxide synthase (iNOS), cyclooxygenase-2 (COX-2) and and cytokines which include tumor necrosis factor- $\alpha$ (TNF- $\alpha)$, interleukin- $1 \beta$ (IL-1 $\beta)$, and IL-6 (19). This inflammation-related process may result in the pathogenesis of various chronic diseases, such as hay fever, periodontitis, atherosclerosis, rheumatoid arthritis, Alzheimer's disease, and even cancer, such as gallbladder carcinoma (20). Therefore, inhibiting NF- $\mathrm{NB}$ and/or various pro-inflammatory mediators could be considered a promising strategy for drug discovery in relation to the treatment of various chronic disease (21). Widely used pharmaceuticals, such as indomethacin, naproxen and etanercept have been designed for the inhibition of specific inflammatory mediators (22). Despite their benefits, such synthetic medicines may cause serious adverse effects (23). Therefore, scientific trials that have been intensively concentrated on plant substances to find more effective and less deleterious therapeutic agents are required. It has been scientifically demonstrated that various compounds of plant species show anti-inflammatory potential (24). The polyphenols are a group of secondary metabolites that are ubiquitously found in the plant kingdom, and exhibit various pharmaceutical effects (25). It is well-known that the polyphenols of oriental herbs can inhibit inflammatory pathways and mediators, such as NF- $\kappa$ B, TNF- $\alpha$, iNOS, and COX-2, IL-1 $\beta$ and IL-6 (26).

Seomae mugwort (SM) is a Korean variety of A. argyi $\mathrm{H}$. Lév. \& Vaniot that is exclusively cultivated on Namhae Island, and has been registered under protection as a local-specific resource by the Korea Forest Service (registration no. 42, 2013, 09. 27) (27). Few studies have been conducted to investigate its chemical and biological characteristics (12). Therefore, further analysis of its chemical composition and biological activities is required. Though previous studies have been conducted on the anti-inflammatory effect of Artemisia polyphenols (28), no information regarding the anti-inflammatory properties of SM polyphenols has been obtained at the molecular level.

In the present study, we aimed to comprehensively characterize the SM polyphenolic metabolomes, such as flavonoid using high-performance liquid chromatography coupled with tandem mass spectrometry (HPLC-MS/MS), and investigated their anti-inflammatory effects.

\section{Materials and methods}

\section{Experimental extraction of polyphenols}

Standards and reagents. Caffeic acid, apigenin, kaempferol, amentoflavone, ferulic acid, quercetin and flavone were purchased from Sigma-Aldrich (Merck KGaA), and used as external standards, after recrystallization in $\geq 99.9 \%$ HPLC-grade methanol. The purities of all standards were confirmed by HPLC to be $>99 \%$. All other chemicals and solvents were of analytical grade, and were obtained from Duksan Pure Chemical Co., Ltd.

Collection and preparation of plant materials. The SM plants were collected in May 2017 from Namhae Island. The Animal Bioresource Research Bank authenticated the plants as taxonomically homozygous. The voucher specimens (ref nos. 2012M3A9B8019303 and 2017R1A2B4003974) were deposited at the herbarium of the Research Institute of Life Science, Gyeongsang National University. The plants were washed with water, lyophilized and stored at $-20^{\circ} \mathrm{C}$, till extraction.

Extraction and purification. The isolation of polyphenols from the plant was carried out based on the technique described by Song et al with minor modifications (29). The lyophilized plants $(90 \mathrm{~g})$ were refluxed in $70 \%$ methanol $(1.5 \mathrm{l})$ for $20 \mathrm{~h}$ at room temperature. The mixture was filtered through a Büchner funnel, and concentrated to $\sim 300 \mathrm{ml}$ at reduced pressure at $35^{\circ} \mathrm{C}$, using a rotary evaporator with $80 \mathrm{rpm}$. The concentrated filtrate was washed with $n$-hexane $(300 \mathrm{ml})$ three times to remove nonpolar impurities. Subsequently, the filtrate was extracted using ethyl acetate $(100 \mathrm{ml})$ three times, and dried over anhydrous $\mathrm{MgSO}_{4}$. The solvent was removed under reduced pressure. The sticky residue was placed on the top of a silica gel solvent $(40 \times 2.5 \mathrm{~cm})$, and eluted with ethyl acetate to eliminate highly polar impurities. The solvent was then removed to yield solids of polyphenol mixture $(1.34 \mathrm{~g}, 1.5 \%$ of the lyophilized plants). The mixture was stored at $-20^{\circ} \mathrm{C}$, pending analysis.

HPLC-MS/MS analysis. HPLC-MS/MS were conducted according to the method previously reported by Song et al (29). HPLC-MS/MS was performed on a 1,100 series HPLC system (Agilent Technologies, Inc.) and 3200 QTrap tandem mass system (Sciex LLC) operated in negative ion mode (spray voltage set at $-4.5 \mathrm{kV}$ ). The exception being only that the gradient system comprised $0.5 \%$ aqueous formic acid (A) and $100 \%$ methanol (B) at a flow rate of $0.5 \mathrm{ml} / \mathrm{min}$. The gradient conditions used in the mobile phase were $0-10 \mathrm{~min}$, $15 \% \mathrm{~B} ; 10-15 \mathrm{~min}, 15-20 \% \mathrm{~B} ; 15-25 \mathrm{~min}, 20 \% \mathrm{~B} ; 25-30 \mathrm{~min}$, $20-25 \% \mathrm{~B} ; 30-60 \mathrm{~min}, 25-45 \% \mathrm{~B}$; $60-65 \mathrm{~min}, 45-70 \% \mathrm{~B}$; 65-70 $\min , 70-15 \% \mathrm{~B}$.

Quantification of polyphenol. Polyphenol samples were quantified using LC-UV chromatograms (at $280 \mathrm{~nm}$ ) with seven selected standards. Calibration curves were plotted for each using five concentration levels $(n=5 ; 50,100,200,500$, and $1,000 \mu \mathrm{g} / \mathrm{ml}$ ) and polyphenol contents were determined in terms of peak area ratios with the analyte vs. analyte concentrations using a $1 / x$ ( $x$, concentration) weighted linear regression $(n=5)$. Quantification of each polyphenol can be conducted using a standard with the same chromophore. Thus, the standard caffeic acid was used to quantify compounds 1, 6, 10, 11 and 14; apigenin was used to quantify compounds 2 and 3; kaempferol was used for compounds 8 and 9; amentoflavone was applied for compounds 5 and 7, followed by ferulic acid, quercetin, and flavone was used to quantify compounds 4, 12 and 13, respectively. And all samples were repeated three or more times.

\section{Anti-inflammatory experiments}

Cell culture. The mouse macrophage cells, RAW 264.7 (American Type Culture Collection), were cultured in Dulbecco's Modified Eagles medium (HyClone; GE Healthcare Life Sciences) supplemented with $10 \%$ fetal bovine serum and $100 \mathrm{U} / \mathrm{ml}$ streptomycin at $37^{\circ} \mathrm{C}$ in humidified $5 \% \mathrm{CO}_{2}$ incubator. 
Cell viability assay. Cell viability was evaluated with MTT assay. RAW 264.7 cells were seeded at a density of $5 \times 10^{4}$ per well in 48-well culture plates. The cells were stimulated with LPS at $1 \mu \mathrm{g} / \mathrm{ml}$ for $1 \mathrm{~h}$ and then incubated with SM polyphenols at the indicated concentration $(2.5-30 \mu \mathrm{g} / \mathrm{ml})$ for $24 \mathrm{~h}$ at $37^{\circ} \mathrm{C}$. Control and LPS-only treated groups were treated with the same volume of the solvent dimethyl sulfoxide. After washing the cells, $0.05 \%$ MTT solution was added to each well, and then incubated for $3 \mathrm{~h}$ at $37^{\circ} \mathrm{C}$. The formazan crystals in live cells were dissolved in dimethyl sulfoxide. The absorbance of each well was measured at $570 \mathrm{~nm}$ using PowerWave HT microplate spectrophotometry (BioTek, Inc.). The cell viability was expressed as a percentage of viable cells compared with the control group consisting of untreated cells.

Measurement of nitric oxide (NO) expression. The quantitation of NO expression in biological systems was analyzed using Griess reagent kit (Promega Corporation, TB229), according to the manufacturer's instructions. RAW 264.7 cells were seeded at a density of $1.5 \times 10^{4}$ per well in 96 -well culture plates. RAW 264.7 cells were then pretreated with $1 \mu \mathrm{g} / \mathrm{ml}$ LPS for $1 \mathrm{~h}$, followed by treatment with SM polyphenols at a concentration of 2.5 and $5 \mu \mathrm{g} / \mathrm{ml}$ for $24 \mathrm{~h}$ at $37^{\circ} \mathrm{C}$. The mixture of $50 \mu \mathrm{l}$ of cell culture supernatant and $50 \mu \mathrm{l}$ of sulfanilamide solution (1\% sulfanilamide in $5 \%$ phosphoric acid) was incubated in 96-well plate for $10 \mathrm{~min}$ at room temperature, protected from light. After incubation, $50 \mu \mathrm{l}$ of N-(1-naphthyl) ethylene diamine hydrochloride solution was added to each mixture, and incubated for $10 \mathrm{~min}$ at room temperature, protected from light. The absorbance of each well was measured at a wavelength of $520 \mathrm{~nm}$ using PowerWave HT microplate spectrophotometer (BioTek Instruments, Inc.). To calibrate the amount of NO, sodium nitrite $(0,1.56,3.13,6.25,12.5,25,50$, and $100 \mu \mathrm{M}$ ) was used as the nitrate standard.

Enzyme-linked immunosorbent assay (ELISA). RAW 264.7 cells were seeded at a density of $5 \times 10^{4}$ per well in 48 -well culture plates. The cells were pretreated with $1 \mu \mathrm{g} / \mathrm{ml}$ LPS for $1 \mathrm{~h}$ and then incubated with SM polyphenols for $24 \mathrm{~h}$ at $37^{\circ} \mathrm{C}$. The cytokine IL-1 $\beta$ levels were quantified using the mouse IL-1 $\beta$ kit (ADI-900-132A, Enzo Life Sciences) according to the manufacturer's instructions.

Western blot analysis. Whole cell lysates were prepared using radioimmunoprecipitation assay buffer (RIPA; iNtRON; $50 \mathrm{mM}$ Tris- $\mathrm{HCl}, \mathrm{pH} 7.5,150 \mathrm{mM}$ sodium chloride, $0.5 \%$ sodium deoxycholate, $1 \%$ Triton $\mathrm{X}-100,0.1 \%$ SDS, $2 \mathrm{mM}$ EDTA) containing protease inhibitor cocktail (Thermo Fisher Scientific, Inc.) and phosphatase inhibitor (Thermo Fisher Scientific, Inc.). The concentration of proteins was determined by a BCA protein assay kit (Thermo Fisher Scientific, Inc.). An equal amount of protein $(20 \mu \mathrm{g})$ was separated using 8-15\% SDS-PAGE, and transferred onto a polyvinylidene difluoride membrane. The membranes were blocked with $5 \%$ non-fat milk or 5\% bovine serum albumin (Gibco; Thermo Fisher Scientific, Inc.) in Tris-buffered saline with Tween-20 (TBS-T; $25 \mathrm{mM}$ Tris, $137 \mathrm{mM} \mathrm{NaCl}, 2.7 \mathrm{mM} \mathrm{KCl}$, and $0.1 \%$ Tween-20) at room temperature for $1 \mathrm{~h}$, and incubated with the respective primary antibodies at $4^{\circ} \mathrm{C}$ for $16 \mathrm{~h}$. Primary antibodies against iNOS (cat. no. 13120S; 1:1,000), COX-2 (cat. no. 12282S; 1:1,000), phosphorylated (p)-p65 (Ser536; 3033S; 1:1,000), p65 (8242S; 1:1,000), p-IкB $\alpha$ (Ser32; cat. no. 2859S; 1:1,000), IкB $\alpha$ (cat. no. 4812S; 1:1,000), p-JNK1/2 (Thr183/Tyr185; cat. no. 4671S, 1:1,000), JNK (cat. no. 9258S, 1:1,000), p-p38 (Thr180/Tyr182; cat. no. 9216S, 1:1,000), p38 (cat. no. 8690S; 1:1,000), p-ERK1/2 (Thr202/Tyr204; cat. no. 4370S, 1:1,000), ERK1/2 (cat. no. 4695S; 1:1,000), and $\beta$-actin (cat. no. 3700S, 1:10,000) were purchased from Cell Signaling Technology, Inc. After washing with TBS-T more than five times, the membranes were incubated with the anti-rabbit or anti-mouse (cat. nos. A120-101P and A90-116P, respectively, Bethyl Laboratory, Inc.) secondary antibodies $(1: 2,000)$ conjugated with horseradish peroxidase for $3 \mathrm{~h}$ at room temperature, followed by visualization with an enhanced chemiluminescence kit (Bio-Rad Laboratories, Inc.). The images were acquired by the ChemiDoc imaging system (Bio-Rad Laboratories, Inc.). The $\beta$-actin protein was used as a loading control. Western blot images were quantified using the ImageJ 1.50i software (National Institutes of Health).

Reverse transcription-quantitative polymerase chain reaction analysis $(R T-q P C R)$. After treatment, total RNA was extracted from RAW 264.7 cells by using TRIzol reagent (Thermo Fisher Scientific, Inc.). cDNA was reverse-transcribed from $1 \mu \mathrm{g}$ of RNA with iScript cDNA synthesis kit (Bio-Rad Laboratories, Inc.), according to the manufacturer's instructions, and used as templates in quantitative real-time PCR using AccuPower ${ }^{\circledR}$ 2X GreenstarTM qPCR Master (Bioneer, Daejeon, Republic of Korea). The sequence of primers were as follows: iNOS, 5'-TCCTACACCACACCAAAC-3' (forward) and 5'-CTCCAA TCTCTGCCTATC-3' (reverse), IL-1 $\beta$, 5'-TGCAGAGTTCCC CAACTGGTACATC-3' (forward) and 5'-GTGCTGCCTAAT GTCCCCTTGAATC-3' (reverse), TNF $\alpha$, 5'-TGGAGTCAT TGCTCTGTGAAGGGA-3' (forward) and 5'-AGTCCTTGA TGGTGGTGCATGAGA-3' (reverse), $\beta$-actin, 5'-TACTGC CCTGGCTCCTAGCA-3' (forward), and 5'-TGGACAGTG AGGCCAGGATAG-3' (reverse) (30-32). Thermocycling conditions consisted of an pre-denaturation for $2 \mathrm{~min}$ at $95^{\circ} \mathrm{C}$, followed by 40 cycles at $95^{\circ} \mathrm{C}$ for $5 \mathrm{sec}, 58^{\circ} \mathrm{C}$ for $30 \mathrm{sec}$, and $95^{\circ} \mathrm{C}$ for $5 \mathrm{sec}$; qPCR was conducted with a CFX384 Real-Time PCR Detection System (Bio-Rad Laboratories, Inc.). All data was investigated with the Bio-Rad CFX Manager Version 3.1 software. Relative quantitation was analyzed on taking the difference $(\Delta \mathrm{Cq})$. The mRNA expression levels were normalized using the expression of $\beta$-actin.

Statistical analysis. All the results of the anti-inflammatory experiment were presented as the mean \pm standard error of the mean of triplicate samples. Statistical analyses were conducted using GraphPad Prism software version 5.02 (GraphPad Software, Inc.). Significant differences between groups were calculated by one-way factorial analysis of variance, followed by a Dunnett's test. $\mathrm{P}<0.05$ was considered to indicate a statistically significant difference.

\section{Results}

Separation and characterization of SM polyphenols. The mixture of polyphenols isolated from SM by $70 \%$ methanol extraction was followed by the elution of ethyl acetate over 
Table I. High-performance liquid chromatography MS/MS data of polyphenols from Seomae mugwort.

\begin{tabular}{|c|c|c|c|c|c|c|}
\hline Author, year & No. & Compound & $t_{R}(\min )$ & {$[\mathrm{M}-\mathrm{H}]^{-}$} & $\mathrm{MS} / \mathrm{MS}(\mathrm{m} / \mathrm{z})$ & (Refs.) \\
\hline $\begin{array}{l}\text { Dou et al, } 2007 ; \\
\text { Del Rio } \text { et al, } 2004\end{array}$ & 1 & Caffeoylquinic acid isomer & 10.29 & 353 & $353,191,179,135$ & $(53,54)$ \\
\hline Simirgiotis et al, 2013 & 2 & $\begin{array}{l}\text { 6,8-di- } C \text {-glucosylapigenin } \\
\text { (vicenin II) }\end{array}$ & 12.19 & 593 & $\begin{array}{c}593,503,473,413, \\
383,353\end{array}$ & (55) \\
\hline Dou et al, 2007 & 3 & 6-C-Arabinosyl-8-C-glucosylapigenin & 16.60 & 563 & $\begin{array}{c}563,545,503,473, \\
443,383,353\end{array}$ & $(53)$ \\
\hline Fischer et al, 2012 & 4 & Secoisolariciresinol & 24.02 & 361 & $361,346,313,179,165$ & $(34)$ \\
\hline Yao et al, 2017 & 5 & Amentoflavone isomer & 28.70 & 537 & $\begin{array}{c}537,443,417,399 \\
375,357,335 \\
331,201,178 \\
161,117\end{array}$ & $(35)$ \\
\hline $\begin{array}{l}\text { Dou et al, 2007; } \\
\text { Del Rio et al, } 2004\end{array}$ & 6 & Caffeoylquinic acid isomer & 30.89 & 353 & $353,191,179,135$ & $(53,54)$ \\
\hline Yao et al, 2017 & 7 & Amentoflavone isomer & 34.17 & 537 & $537,375,357,179,134$ & $(35)$ \\
\hline Ahmed et al, 2016 & 8 & Kaempferol-3-O-rutinoside & 41.69 & 593 & $593,447,285$ & $(56)$ \\
\hline Ahmed et al, 2016 & 9 & Kaempferol-3-O-glucuronide & 42.83 & 461 & $461,323,285,160$ & $(56)$ \\
\hline Bastos et al, 2007 & 10 & Dicaffeoylquinic acid & 44.79 & 515 & $\begin{array}{l}515,353,191 \\
179,173,134\end{array}$ & $(57)$ \\
\hline $\begin{array}{l}\text { Gouveia and Castilho, } \\
2012\end{array}$ & 11 & $3,4,5-O$-Tricaffeoylquinic acid & 45.01 & 677 & $\begin{array}{c}677,515,353, \\
335,299,191,173\end{array}$ & $(58)$ \\
\hline Li et al, 2018 & 12 & Quercetin dimethyl ether & 46.49 & 329 & $329,314,299,271$ & $(59)$ \\
\hline Luo et al, 2012 & 13 & Skullcapflavone II & 48.12 & 373 & $373,358,343$ & $(40)$ \\
\hline Sanz et al, 2012 & 14 & Calcelarioside A & 51.73 & 477 & $477,179,161$ & (41) \\
\hline
\end{tabular}

$t_{R}$, retention time; MS/MS, tandem mass spectrometry.

a silica gel column. Each polyphenol was characterized via HPLC using a $\mathrm{C}_{18}$ column, MS/MS in negative ion mode, and a comparison with the reported data was performed. The polyphenols were labeled according to their retention time $\left(t_{\mathrm{R}}\right)$ order in the 10-60 min absorbance segment of chromatogram recorded at $280 \mathrm{~nm}$ (Table I). A total of fourteen polyphenols were characterized, which are composed of five hydroxycinnamates (1, 6, 10, 11 and 14), eight flavonoids $(2,3,5,7,8$, 9, 12 and 13) and one lignan (4). As shown in Figs. 1 and 2, and Table I, the structures and HPLC-MS/MS data of the polyphenols were presented. Hydroxycinnamates (1, 6, 10, and 11) and flavonoids (2 and 3 ) were recently reported in Chinese and Korean A. argyi (33). To the best of our knowledge, we are the first to characterize one hydroxycinnamate (14), six flavonoids $(5,7,8,9,12$ and 13), and lignan (4) in the SM variety of A. argyi. It has been known that plant bioactive components may vary in accordance with the plant variety based on geographical location, which is attributed mainly to climatic variation and nutrient availability (12). The novel polyphenols were identified on the basis of their molecular ions and mass fragmentation patterns in comparison with the literature data. Thus, phenolic component $4\left(t_{\mathrm{R}}=24.02 \mathrm{~min}\right)$ yield $[\mathrm{M}-\mathrm{H}]^{-}$at $\mathrm{m} / \mathrm{z} 361$, which was fragmented to ions $\mathrm{m} / \mathrm{z} 346\left[\mathrm{M}-\mathrm{H}-\mathrm{CH}_{3}\right]^{-}$, 313 [M-H-CH$\left.{ }_{2}\right]^{-}, 179\left[\mathrm{C}_{6} \mathrm{H}_{4}(\mathrm{O})\left(\mathrm{OCH}_{3}\right) \mathrm{CH}=\mathrm{CHCH}_{2} \mathrm{OH}\right]^{-}$, and
$165\left[\mathrm{C}_{6} \mathrm{H}_{3}(\mathrm{CO})_{2} \mathrm{CH}_{2} \mathrm{CH}_{2} \mathrm{CH}_{2} \mathrm{Ox}\right]^{-}$, was identified as secoisolariciresinol (34). Flavonoid $5\left(t_{\mathrm{R}}=28.70 \mathrm{~min}\right)$ was identified as amentoflavone isomer, which has shown $[\mathrm{M}-\mathrm{H}]^{-}$at $\mathrm{m} / \mathrm{z} 537$, and fragmented to generate an ion at $\mathrm{m} / \mathrm{z} 443\left[\mathrm{M}-\mathrm{H}-\mathrm{C}_{6} \mathrm{H}_{5} \mathrm{OH}\right]^{-}$, 417 [C ring 0,2 cleavage, $\left.\mathrm{M}-\mathrm{H}-\mathrm{C}_{6} \mathrm{H}_{4}(\mathrm{O}) \mathrm{CO}\right]^{-}, 399$ [ $\mathrm{C}^{\prime}$ ring 0',3' cleavage, $\left.\mathrm{M}-\mathrm{H}-\mathrm{C}_{6} \mathrm{H}_{2}(\mathrm{OH})_{2} \mathrm{CO}-2 \mathrm{H}\right]^{-}, 375$ [C ring 0,4 retro-Diels Alder fragment, M-H-C ${ }_{6} \mathrm{H}_{4}(\mathrm{OH}) \mathrm{C}(\mathrm{O}) \mathrm{CHCO}^{-}, 331$ [M-H-(A' $\left.+\mathrm{C}^{\prime}\right)$ rings-CO$]^{-}$and $117\left[\mathrm{C}_{6} \mathrm{H}_{4}(\mathrm{OH}) \mathrm{C}=\mathrm{C}\right]^{-}(35)$. Flavonoid $7\left(t_{\mathrm{R}}=34.17 \mathrm{~min}\right)$ was also identified as an amentoflavone isomer, which showed the similar fragmentation pattern $[\mathrm{M}-\mathrm{H}]^{-}$as flavonoid 5. Three amentoflavone type isomers (molecular weight=538, amentoflavone, robustaflavone and hinokiflavone) have been reported until now (36). However at present, it is unclear which of the three isomers should be assigned to 5 or 7 , because the MS/MS data are not sufficient to exactly characterize the atomic connectivity of the isomers. Therefore, for exact identification and confirmation, further spectroscopic investigation should be performed. Flavonoid $8\left(t_{\mathrm{R}}=41.69 \mathrm{~min}\right)$ yielded $[\mathrm{M}-\mathrm{H}]^{-}$at $\mathrm{m} / \mathrm{z} 593$ with additional peaks observed at $\mathrm{m} / \mathrm{z} 447$ [M-H-rhamnosyl] ${ }^{-}$and 285 [kampferol aglycon] ${ }^{-}$, and this component was identified as kaempferol 3- $O$-rutinoside (37). Flavonoid $9\left(t_{\mathrm{R}}=42.83 \mathrm{~min}\right)$ yielded $[\mathrm{M}-\mathrm{H}]^{-}$at $\mathrm{m} / \mathrm{z} 461$, and showed an additional fragmented peak at 285 [kampferol aglycon, M-H-glucuronyl]', 
<smiles>[R6]OC1CC([R6])(C(=O)O)CC([R6])C1O</smiles>

1,6: $\mathrm{R}_{1}+\mathrm{R}_{2}+\mathrm{R}_{3}+\mathrm{R}_{4}=3 \mathrm{H}+$ caffeoyl

10: $\mathrm{R}_{1}+\mathrm{R}_{2}+\mathrm{R}_{3}+\mathrm{R}_{4}=2 \mathrm{H}+2$ caffeoyl

11: $\mathrm{R}_{1}+\mathrm{R}_{2}+\mathrm{R}_{3}+\mathrm{R}_{4}=\mathrm{H}+3$ caffeoyl<smiles>COc1cc(CC(CO)C(CO)Cc2ccc(O)c(OC)c2)ccc1O</smiles>

4<smiles>[R6]c1cc([R5])c(-c2oc3c([R6])c([R3])c([R2])c(O)c3c(=O)c2[R8])c([R6])c1[2H]</smiles>

2: $\mathrm{R}_{1}=\mathrm{R}_{5}=\mathrm{R}_{7}=\mathrm{R}_{8}=\mathrm{H}, \mathrm{R}_{2}=\mathrm{R}_{4}=$ glucosyl, $\mathrm{R}_{3}=\mathrm{R}_{6}=\mathrm{OH}$

3: $\mathrm{R}_{1}=\mathrm{R}_{5}=\mathrm{R}_{7}=\mathrm{R}_{8}=\mathrm{H}, \mathrm{R}_{2}=$ glucosyl, $\mathrm{R}_{3}=\mathrm{R}_{6}=\mathrm{OH}, \mathrm{R}_{4}=$ arabinosyl

5, 7: $R_{1}=R_{5}=R_{7}=R_{8}=H, R_{2}+R_{4}=$ apigenyl $+H, R_{3}=R_{6}=O H$

8: $R_{1}=$ O-rutinosyl, $R_{2}=R_{4}=R_{5}=R_{7}=R_{8}=H, R_{3}=R_{6}=O H$

9: $\mathrm{R}_{1}=\mathrm{O}$-glucosyl, $\mathrm{R}_{2}=\mathrm{R}_{4}=\mathrm{R}_{5}=\mathrm{R}_{7}=\mathrm{R}_{8}=\mathrm{H}, \mathrm{R}_{3}=\mathrm{R}_{6}=\mathrm{OH}$

12: $R_{1}=R_{6}=O_{3} H_{3}, R_{2}=R_{4}=R_{5}=R_{7}=R_{8}=H, R_{3}=R_{7}=O H$

13: $R_{1}=R_{6}=R_{7}=H, R_{2}=R_{3}=R_{4}=R_{5}=O_{C H}, R_{8}=H$<smiles>O=C(/C=C/c1ccc(O)c(O)c1)OC1C(CO)CC(OCCc2ccc(O)c(O)c2)C(O)C1O</smiles>

14

Figure 1. Structure of the polyphenols in Artemisia argyi.

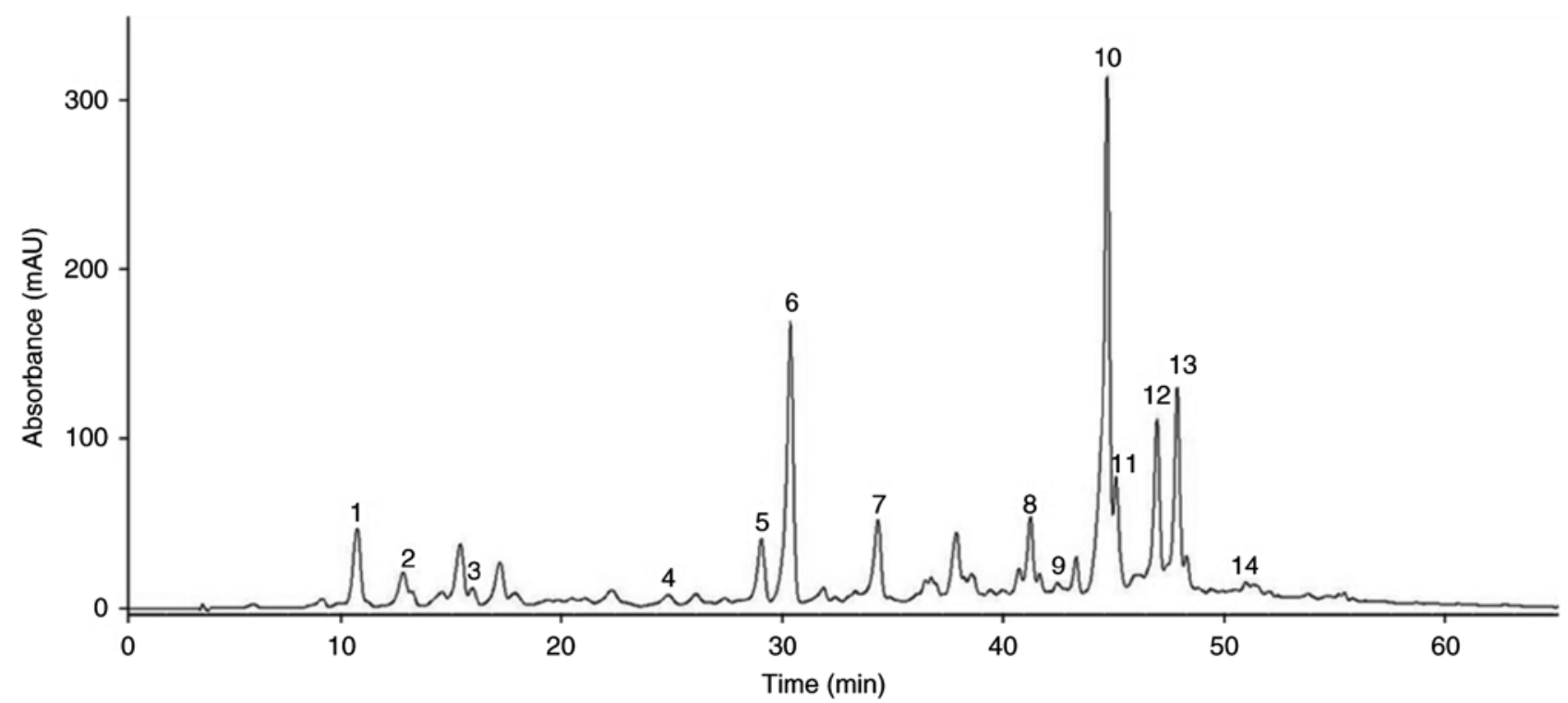

Figure 2. High-performance liquid chromatography of polyphenols of Artemisia argyi.

which was identified as kaempferol-3-O-glucuronide (38). Flavonoid $12\left(t_{\mathrm{R}}=46.49 \mathrm{~min}\right)$ yielded $[\mathrm{M}-\mathrm{H}]^{-}$at $\mathrm{m} / \mathrm{z} 329$, which was fragmented to ions at $\mathrm{m} / \mathrm{z} 314\left[\mathrm{M}-\mathrm{H}-\mathrm{CH}_{3}\right]^{-}, 299$ [quercetin aglycon, $\left.\mathrm{M}-\mathrm{H}-2 \mathrm{CH}_{3}\right]^{-}$, and 271 [quercetin aglycon- $\mathrm{CO}{ }^{-}$, and was identified as quercetin dimethyl ether (39). Flavonoid 13 $\left(t_{\mathrm{R}}=48.12 \mathrm{~min}\right)$ was identified as skullcapflavone II, which showed [M-H] $]^{-}$at $\mathrm{m} / \mathrm{z} 373$, which was fragmented to generate an ion at m/z $358\left[\mathrm{M}-\mathrm{H}-\mathrm{CH}_{3}\right]^{-}$and $343\left[\mathrm{M}-\mathrm{H}-2 \mathrm{CH}_{3}\right]^{-}$(40). Hydroxycinnamate $(14)\left(t_{\mathrm{R}}=51.73 \mathrm{~min}\right)$ was identified as calcelarioside A, and its MS/MS showed [M-H] ${ }^{-}$at m/z 477, which was fragmented to 315 [M-H-caffeoyl]', 179 [caffeic acid-H]

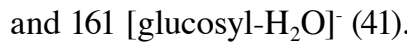

Validation and quantification of SM polyphenols. Quantification of the individual polyphenols was performed using calibration curves obtained from structurally related external standards as described above. As presented in Table II, satisfactory validation data were obtained for the parameters considered. The calibration curve $\left(\mathrm{R}^{2}\right)$ was found to be $\geq 0.9714$. The limits of detection and limits of quantitation 
Table II. Calibration curves and validation data for quantification of polyphenols in Seomae mugwort.

\begin{tabular}{lcccccc}
\hline & & & & \multicolumn{2}{c}{ Recovery $(\%) \pm$ RSD } \\
\cline { 5 - 7 } Standard & Calibration curve & $\mathrm{R}^{2}$ & LOD $(\mathrm{mg} / \mathrm{l})$ & LOQ $(\mathrm{mg} / \mathrm{l})$ & $50 \mathrm{mg} / \mathrm{ml}$ & $100 \mathrm{mg} / \mathrm{ml}$ \\
\hline Catechin & $\mathrm{y}=13.58 \mathrm{x}+147$ & 0.9962 & 2.95 & 8.95 & $80.9 \pm 7.1$ & $98.5 \pm 6.2$ \\
Caffeic acid & $\mathrm{y}=67.66 \mathrm{x}+80.2$ & 0.9954 & 1.15 & 3.47 & $90.9 \pm 6.4$ & $90.3 \pm 4.4$ \\
Ferulic acid & $\mathrm{y}=59.25 \mathrm{x}+93.3$ & 0.9914 & 1.00 & 3.01 & $98.1 \pm 6.1$ & $100.3 \pm 5.7$ \\
Apigenin & $\mathrm{y}=33.87 \mathrm{x}+31.8$ & 0.9998 & 2.96 & 8.95 & $93.7 \pm 3.4$ & $93.3 \pm 2.3$ \\
Quercetin & $\mathrm{y}=44.86 \mathrm{x}-133$ & 0.9975 & 1.81 & 5.49 & $85.7 \pm 7.1$ & $88.1 \pm 5.3$ \\
Kaempferol & $\mathrm{y}=43.96 \mathrm{x}-58.4$ & 0.9983 & 1.10 & 3.34 & $90.8 \pm 7.5$ & $80.6 \pm 9.1$ \\
Amentoflavone & $\mathrm{y}=39.64 \mathrm{x}+70.9$ & 0.9911 & 1.08 & 3.24 & $91.7 \pm 5.9$ & $89.7 \pm 4.2$ \\
Flavone & $\mathrm{y}=55.20 \mathrm{x}+201$ & 0.9714 & 1.67 & 5.07 & $81.4 \pm 5.1$ & $80.3 \pm 3.8$ \\
\hline
\end{tabular}

$\mathrm{y}$, peak area of standard; $\mathrm{x}$, concentration of standard (mg/l); LOD, limit of detection; LOQ, limit of quantitation; RSD, relative standard deviation.

Table III. Content of polyphenols in Seomae mugwort.

\begin{tabular}{lr}
\hline Compounds & Amount $(\mathrm{mg} / \mathrm{kg}$ of dried plant $)$ \\
\hline 1 & $7.25 \pm 0.41$ \\
6 & $58.91 \pm 0.54$ \\
10 & $19.90 \pm 0.31$ \\
11 & $0.84 \pm 0.11$ \\
14 & $0.65 \pm 0.04$ \\
Total hydroxycinnamates & $87.55 \pm 0.75$ \\
2 & $0.92 \pm 0.03$ \\
3 & $0.30 \pm 0.02$ \\
5 & $12.18 \pm 0.51$ \\
7 & $15.83 \pm 1.17$ \\
8 & $0.21 \pm 0.01$ \\
9 & $0.11 \pm 0.01$ \\
12 & $3.67 \pm 0.11$ \\
13 & $3.59 \pm 0.29$ \\
Total flavonoids & $36.81 \pm 1.31$ \\
4 & $0.97 \pm 0.01$ \\
Total & $125.34 \pm 1.31$ \\
\hline
\end{tabular}

were between 1.00-2.96 and 3.01-8.95 mg/l, respectively. Recoveries at 50 and $100 \mathrm{mg} / \mathrm{ml}$ were between 80.9-98.1 and $80.3-100.3 \%$, respectively. The relative standard deviation values were in the ranges of 3.4-7.5 and 2.3-9.1\%, respectively.

The contents of the individual components were listed in Table III. The total hydroxycinnamate content was $\sim 2$-folds higher than that of flavonoids. Among the hydroxycinnamates, caffeoyl quinates $(1,6,10$ and 11$)$ were predominant, and in the case of flavonoids, amentoflavones (5 and 7) were found to be abundant. Additionally, $>90 \%$ of the total isolated compounds were found to be caffeoyl quinates and amentoflavones derivatives.

Anti-inflammatory effects of SM polyphenols on RAW 264.7 macrophage cells. Our results indicated that $>90 \%$ of the SM polyphenols were composed of caffeoyl quinates and amentoflavones, which have been known to possess various pharmacological activities, including anti-oxidant, anti-viral, anti-depressant and anti-inflammatory effects $(36,42)$. The alcoholic extract of A. argyi was recently studied for its anti-inflammatory effects (9), but that of $A$. argyi polyphenols remains unclear. Thus, we further investigated this property in SM.

Cytotoxicity of SM polyphenols on RAW 264.7 cells. An MTT assay was used to investigate the potential cytotoxic effects of SM polyphenols. RAW 264.7 macrophage cells were treated with SM polyphenols at a concentration range of $2.5-30 \mu \mathrm{g} / \mathrm{ml}$ with or without LPS $(1 \mu \mathrm{g} / \mathrm{ml})$ for $24 \mathrm{~h}$. SM polyphenols at a concentration of 2.5 and $5 \mu \mathrm{g} / \mathrm{ml}$ did not exhibit significant cytotoxicity to RAW 264.7 macrophages in both LPS-treated and untreated cell group of cells. On the contrary, significant cytotoxicity was reported for cells treated with $\geq 10 \mu \mathrm{g} / \mathrm{ml} \mathrm{SM}$ in the presence or absence of LPS, compared with the control group of cells (Fig. 3A and B).

Effects of SM polyphenols on LPS-induced NO production and protein expression of iNOS in RAW 264.7 cells. In order to investigate the inhibitory effects of SM polyphenols on NO formation in LPS-induced RAW 264.7 cells, $\mathrm{NO}_{2}^{-}$production was measured by a Griess assay. As shown in Fig. 4A, NO production followed by LPS-treatment was increased significantly by 5-fold, compared with that of non-induced cells. SM polyphenols were determined to significantly inhibit LPS-induced NO production in a dose-dependent manner. The protein expression of iNOS and COX-2 were investigated by a western blot assay. The proteins iNOS and COX-2 are involved in $\mathrm{NO}$ and prostaglandin-endoperoxide synthesis, respectively. LPS could significantly increase the expression of iNOS in LPS-stimulated RAW 264.7 cells, compared with that of unstimulated cells. Treatment with SM polyphenols revealed a significant decrease in LPS-stimulated iNOS expression in a dose-dependent manner (Fig. 4B). On the contrary, SM polyphenols did not notably affect the protein expression of COX-2; LPS induced a significant upregulation in COX-2 expression compared with the control. 

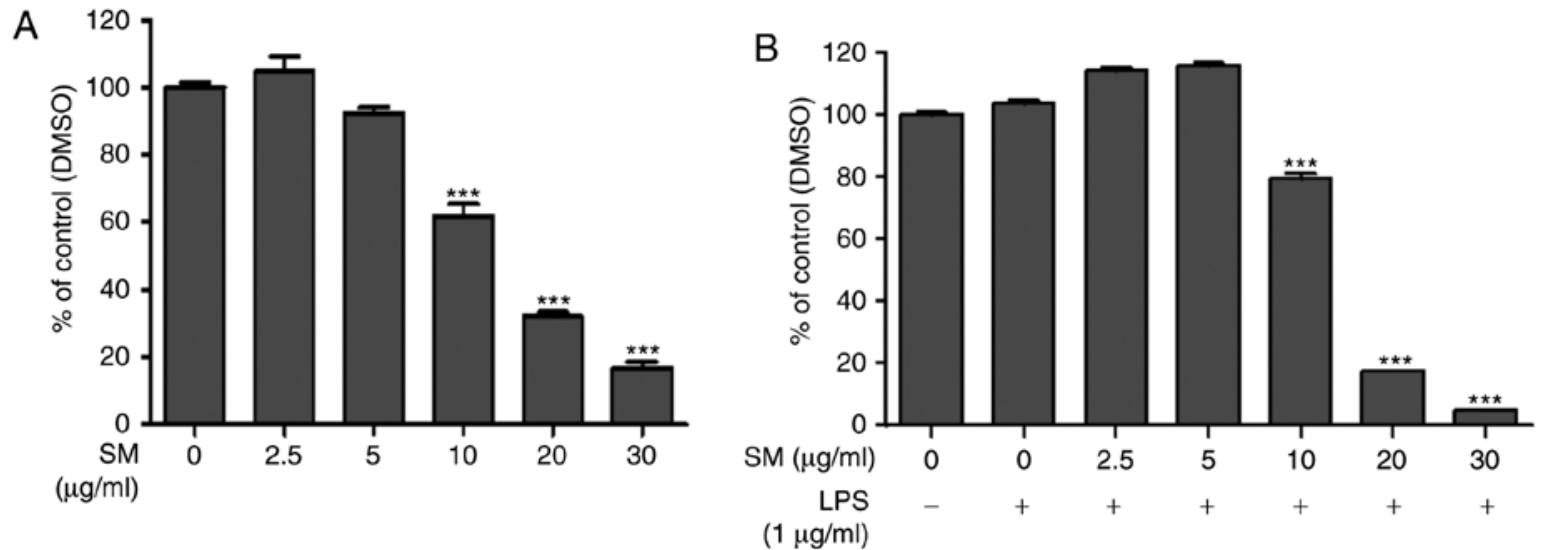

Figure 3. Cytotoxicity of SM polyphenol on RAW264.7 cells. (A) Cells were incubated with different concentrations of SM polyphenols (2.5-30 $\mu \mathrm{g} / \mathrm{ml})$ for $24 \mathrm{~h}$. (B) Cells were pretreated with $1 \mu \mathrm{g} / \mathrm{ml}$ of LPS for $1 \mathrm{~h}$, and then treated with different concentrations of SM polyphenols $(2.5-30 \mu \mathrm{g} / \mathrm{ml})$ for $24 \mathrm{~h}$. Percentage of cell viability was measured via an MTT assay. ${ }^{* * *} \mathrm{P}<0.001$ vs. LPS-treated group. DMSO, dimethyl sulfoxide; LPS, lipopolysaccharide; SM, Seomae mugwort.
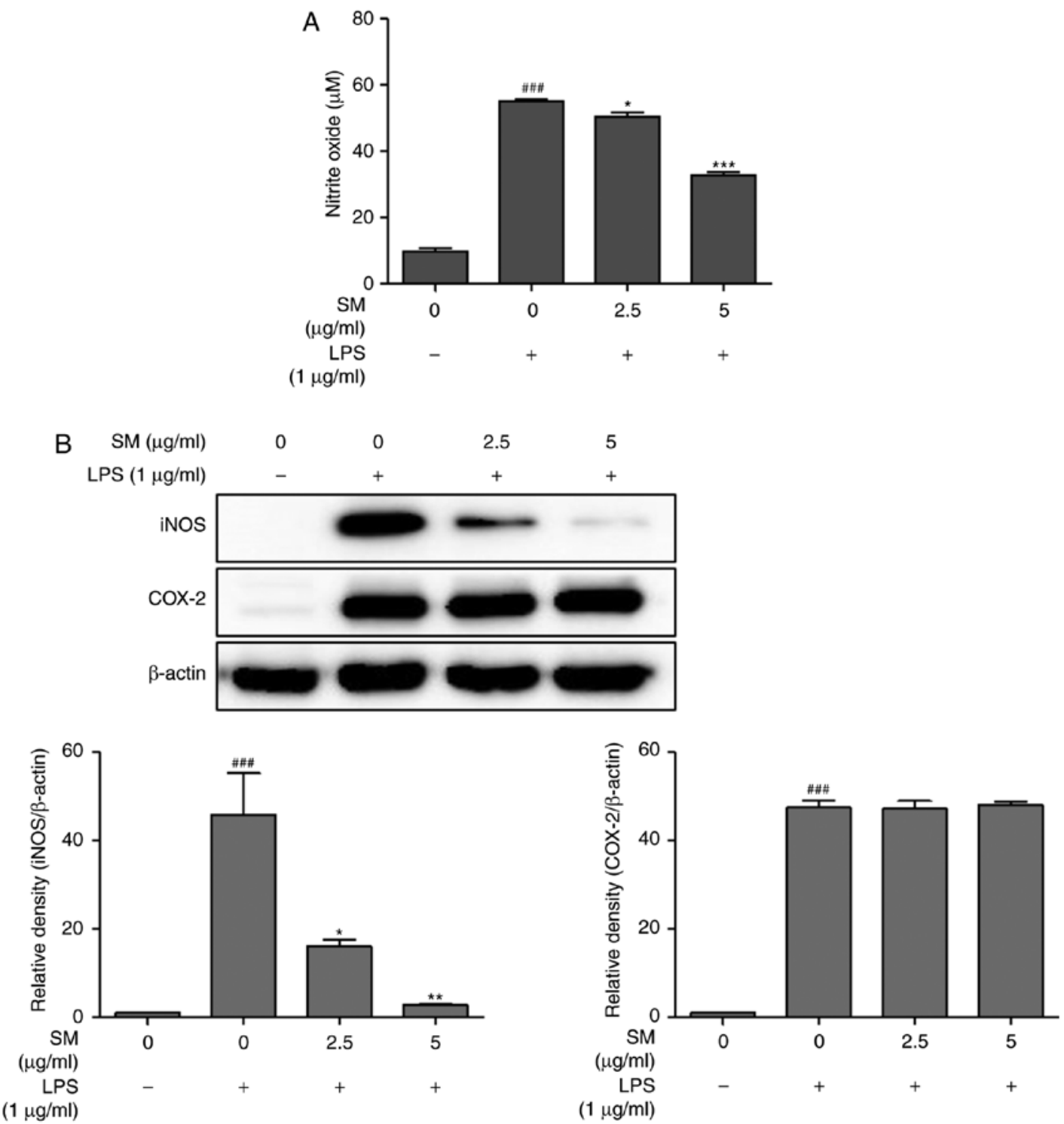

Figure 4. Effects of SM polyphenols on LPS-induced nitrite oxide production and protein expression of iNOS in RAW 264.7 cells. Cells were pretreated and stimulated with LPS for $1 \mathrm{~h}$, and then treated with the indicated concentration of SM polyphenols for $24 \mathrm{~h}$. (A) The cell culture media were measured for the amount of NO formation. (B) The protein expression of expression levels of iNOS and COX- 2 were determined by western blotting. $\beta$-actin was used as a loading control. ${ }^{\# \# *} \mathrm{P}<0.001$ vs. untreated group; ${ }^{\mathrm{P}} \mathrm{P}<0.05,{ }^{* *} \mathrm{P}<0.005$ and ${ }^{* * * *} \mathrm{P}<0.001$ vs. LPS-treated group. COX-2, cyclooxygenase-2; iNOS, inducible nitric oxide synthase; LPS, lipopolysaccharide; SM, Seomae mugwort. 

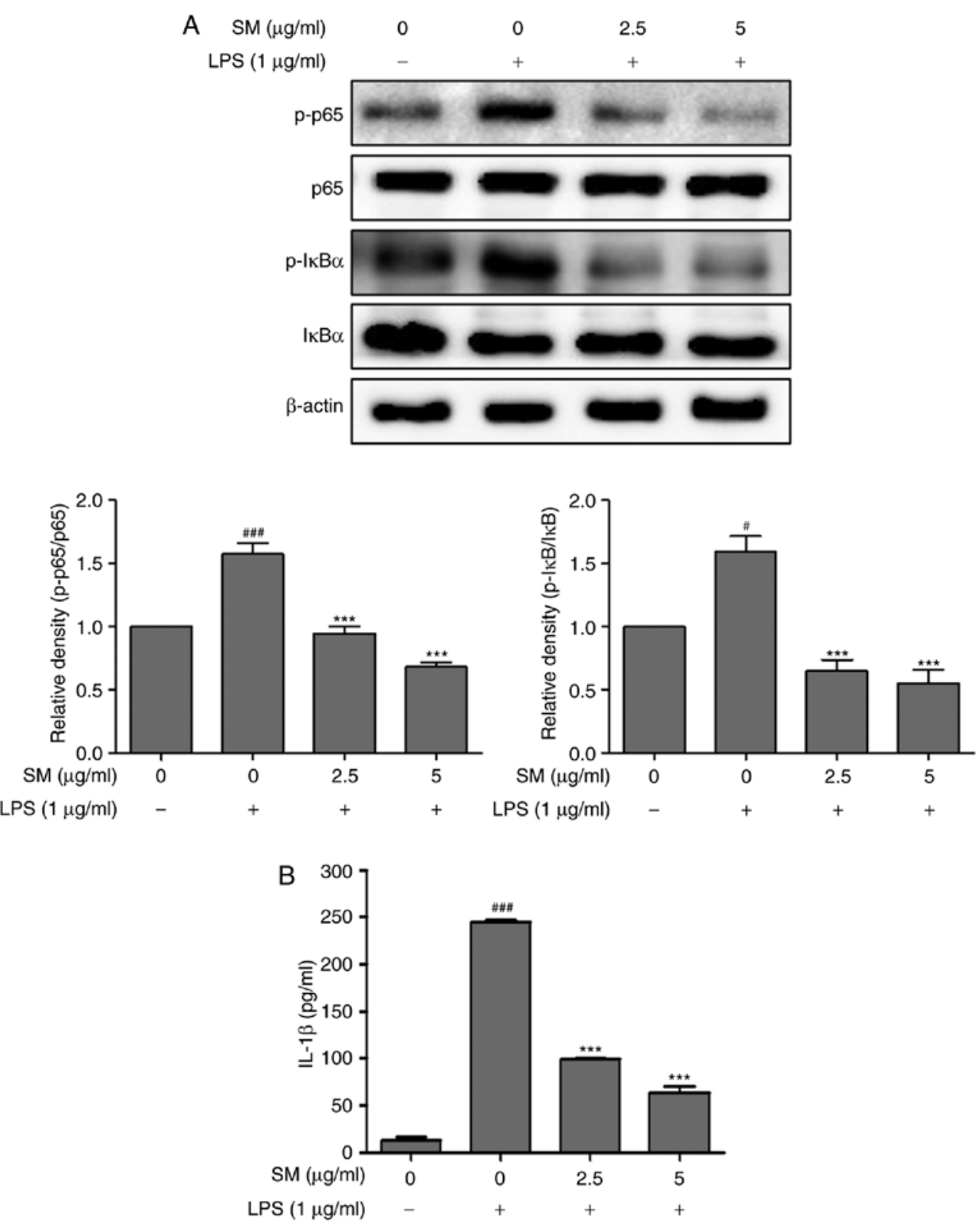

Figure 5. Effects of SM polyphenols on the activation of NF- $\mathrm{kB}$ and expression of IL-1 $\beta$ in LPS-stimulated RAW 264.7 cells. (A) Cells were pretreated with LPS for $1 \mathrm{~h}$, and then incubated with the indicated concentrations of SM polyphenols for $3 \mathrm{~h}$. The activation of NF-kB was investigated by western blot assay. (B) Cells were stimulated with LPS for $1 \mathrm{~h}$, and SM polyphenols were treated with the indicated concentration for $24 \mathrm{~h}$. IL-1 $\beta$ level was measured by ELISA.

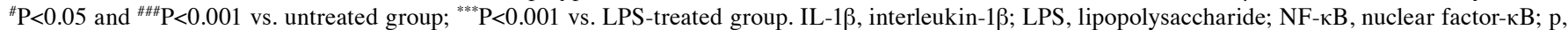
phosphorylated; SM, Seomae mugwort.

Effects of SM polyphenols on NF- $\kappa B$ and inflammatory cytokines in LPS-stimulated RAW 264.7 cells. The ability of SM polyphenols to induce the expression of the cytokines via iNOS was examined in LPS-induced RAW 264.7 macrophage cells. The activation of NF- $\mathrm{KB}$ and the mRNA levels of cytokines following LPS treatment were investigated by western blotting and RT-qPCR, respectively. The expression levels of IL-1 $\beta$ were measured using ELISA. The SM polyphenols significantly attenuated the upregulation of IL-1 $\beta, \mathrm{p}-\mathrm{NF}-\kappa \mathrm{B}$ (p-p65 and $\mathrm{p}-\mathrm{I} \kappa \mathrm{B} \alpha$ ) induced by LPS in a dose-dependent manner, also decreased the mRNA expression of $i N O S$, $T N F \alpha$, and $I L-1 \beta$ (Figs. 5 and 6). These results indicate that SM polyphenols effectively inhibited the NF- $\kappa B$ pathway, and the protein and mRNA expression of cytokines involved in the inflammatory process.
Effects of SM on the phosphorylation of MAPKs in LPS-stimulated RAW 264.7 cells. To determine the relevance of the MAPK pathway with SM polyphenols, we examined the effects of the SM polyphenols on the phosphorylation of JNK, p38 and ERK. Treatment with SM polyphenols significantly suppressed the phosphorylation of the JNK, p38 and ERK in a dose-dependent manner when induced by LPS (Fig. 7). These findings suggest that the SM polyphenols exhibit anti-inflammatory effects by regulating the activation of NF- $\kappa \mathrm{B}$ and MAPK pathways.

\section{Discussion}

A. argyi is a traditional Asian medicinal remedy for diarrhea, hemostasis and inflammation. SM is a Korean variety of 

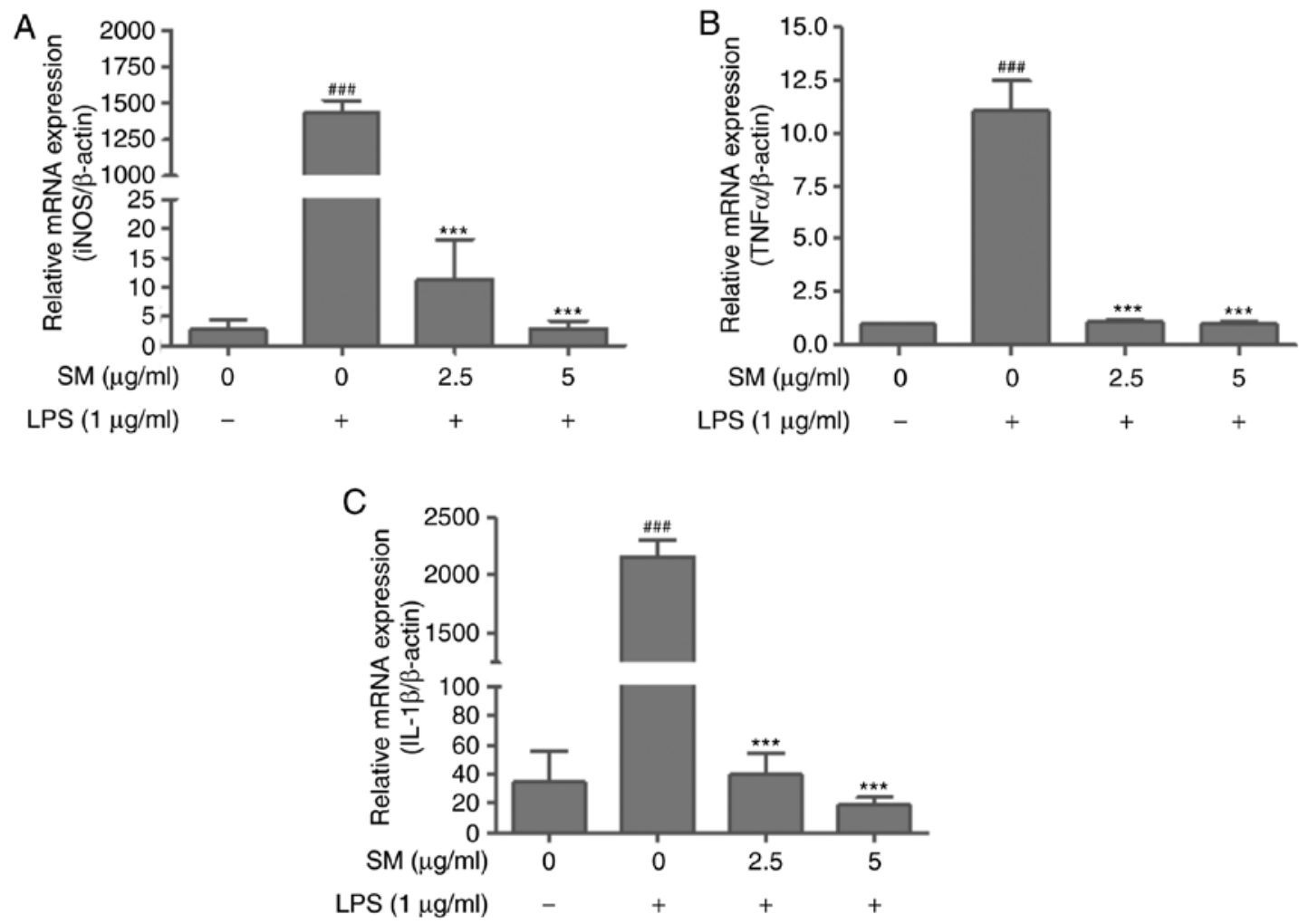

Figure 6. Inhibitory effects of SM polyphenols on the mRNA expression of pro-inflammatory factors in LPS-stimulated RAW 264.7 cells. Cells were pretreated with LPS for $1 \mathrm{~h}$, and then incubated with the indicated concentrations of SM polyphenols for $16 \mathrm{~h}$. The mRNA expression levels of (A) iNOS, (B) TNFo and (C) IL-1 $\beta$ were analyzed by reverse transcription-quantitative polymerase chain reaction, and normalized using $\beta$-actin. ${ }^{\# \# "} \mathrm{P}<0.001$ vs. untreated group; ${ }_{* * * *}^{*}<0.001$ vs. LPS-treated group. IL-1 $\beta$, interleukin-1 $\beta$; LPS, lipopolysaccharide; SM, Seomae mugwort; TNF $\alpha$, tumor necrosis factor $\alpha$.
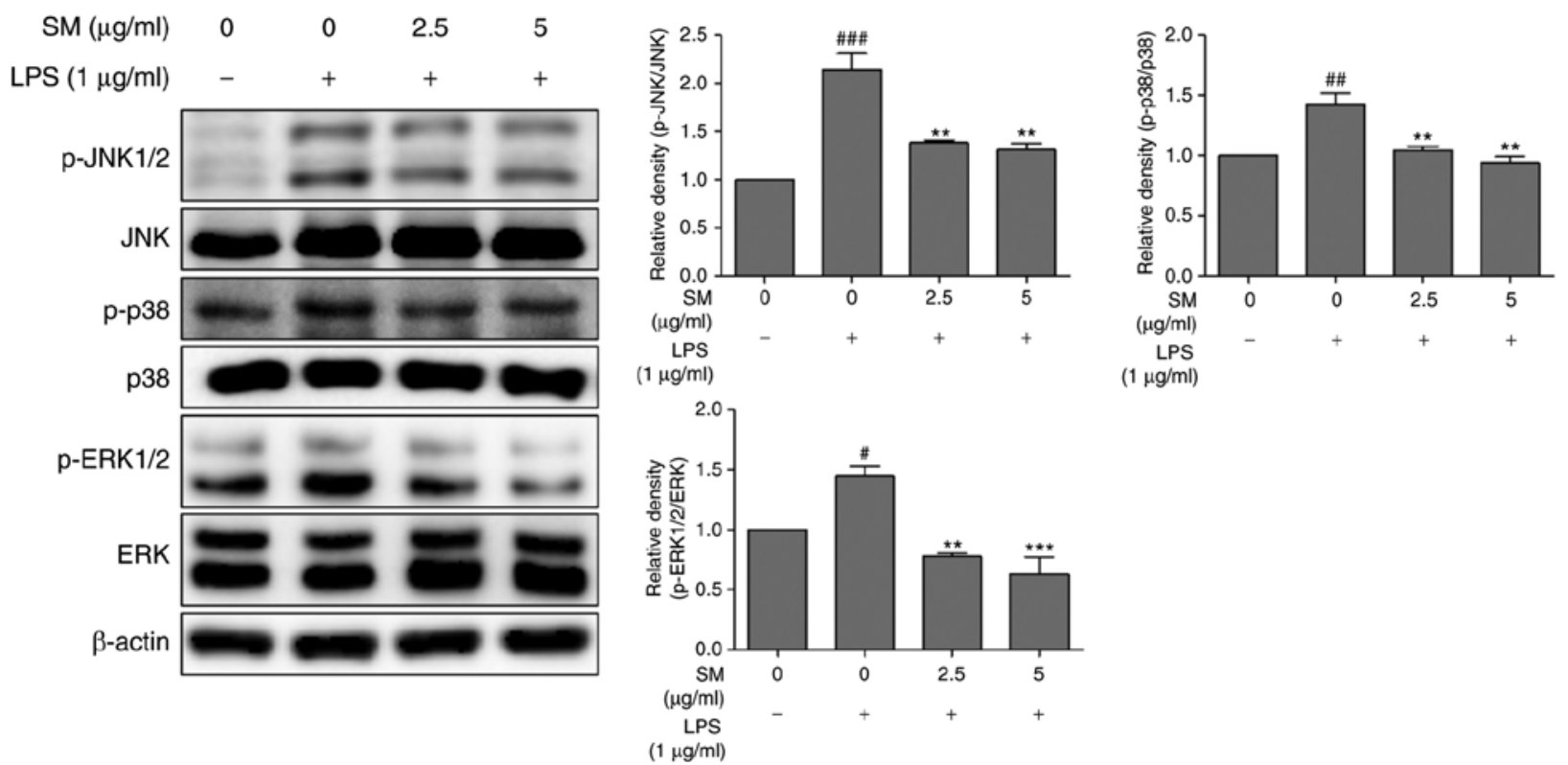

Figure 7. Effects of SM polyphenols on the phosphorylation of MAPKs in LPS-stimulated RAW 264.7 cells. Cells were pretreated with LPS for $1 \mathrm{~h}$, and then incubated with the indicated concentrations of SM polyphenols for $3 \mathrm{~h}$. The protein expression levels of MAPKs (JNK1/2, p38 and ERK1/2) were measured by western blotting. ${ }^{\# \# \#} \mathrm{P}<0.001,{ }^{\# \#} \mathrm{P}<0.005$ and ${ }^{\#} \mathrm{P}<0.05$ vs. untreated group; ${ }^{* *} \mathrm{P}<0.005$ and ${ }^{* * * *} \mathrm{P}<0.001$ vs. LPS-treated group. ERK, extracellular signal-related kinase; JNK, c-Jun N-terminal kinase; p, phosphorylated.

A. argyi harvested in Namhae, Korea. The alcoholic extract of A. argyi was recently studied for its anti-inflammatory effect (9), but that of A. argyi polyphenols has remained unknown until now. In the present study, the anti-inflammatory effects of polyphenol extract form of SM on LPS-stimulated RAW 264.7 mouse macrophage cells were investigated. Among the 14 components profiled via a single HPLC-MS/MS, one hydroxycinnamate, six flavonoids and one lignan were reported for 
the first time in A. argyi. Our quantification analysis based on the validated methods indicated that $>90 \%$ of the total compounds comprised caffeoyl quinates and amentoflavones, which have been known to possess various pharmacological activities, including anti-oxidant, anti-viral, anti-depressant and anti-inflammatory effects $(36,42)$. In the present study, we investigated the anti-inflammatory effect of SM polyphenols.

Additionally, the total content $(125.34 \mathrm{mg} / \mathrm{kg})$ was calculated by the sum of each isolated phenol compound and identified by HPLC analysis. As the lyophilized sample was subjected to liquid-liquid extraction to remove lipophilic impurities, such as fatty acids, the silica column was subjected to the removal of sugars and proteins before the HPLC analysis. Therefore, there may be a difference in the content between the substances purified by the gel column of raw samples and some phenolic compounds detected by their HPLC analysis at $280 \mathrm{~nm}$.

Nitric oxide synthases (NOSs) are composed of three types of enzyme (iNOS, endothelial NOS and neuronal NOS) that catalyze the production of NO from L-arginine (43). iNOS is involved in the immune response-like secretion of pro-inflammatory cytokines through the increased production of NO (43). NO radicals serve a crucial role in regulating inflammation and immune responses in asthma and inflammatory bowel diseases (44). In the process of inflammation, cellular NO is immediately oxidized to $\mathrm{NO}_{2}^{-}$(45). As expected, treatment with SM polyphenols inhibited NO production in our study. In addition, the protein expression of iNOS was decreased, but no significant reduction in the expression level of COX-2 was observed by SM polyphenols in LPS-stimulated RAW 264.7 cells. This discordant result may be attributed to the degree of reliance of the transcription factors required for the expression of iNOS and COX-2 (46).

Activation of transcription factor $N F-\kappa B$ has been considered as the pivotal factor to regulate the expression of inflammatory enzymes and cytokines, such as iNOS, TNF $\alpha$ and IL- $1 \beta$, which comprise the NF- $\kappa \mathrm{B}$ binding sites in their promoters (47). Therefore, the proper regulation of $\mathrm{NF}-\kappa \mathrm{B}$ could be useful in the treatment of many inflammation-related disorders, such as allergies, cancer, dermatitis and arthritis (48-50). The activation of NF- $\mathrm{KB}$ and the increased mRNA levels of cytokines following LPS treatment were investigated by western blot and RT-qPCR analyses, respectively. The levels of IL-1 $\beta$ were measured using ELISA. SM polyphenols were observed to attenuate the upregulation of IL-1 $\beta$, phosphorylated NF- $\kappa \mathrm{B}$ (p-p65 and p-I $\kappa \mathrm{B} \alpha$ ), and increases in the mRNA expression of iNOS, TNF $\alpha$ and IL-1 $\beta$ in a dose-dependent manner. These results indicated that SM polyphenols effectively inhibit the NF- $\mathrm{NB}$ pathway, and the protein and mRNA expression of cytokines involved in the inflammatory process.

During the inflammatory process, the phosphorylation of MAPKs, in which serine and threonine protein kinases perform a crucial role in the transcriptional regulation, mediates LPS-stimulated iNOS and COX2 expression through $\mathrm{NF}-\kappa \mathrm{B}$ activation $(51,52)$. To determine the relevance of the MAPK pathway with SM polyphenols, we examined the effects of the SM polyphenols on JNK, ERK and the p38 phosphorylation levels. Treatment with SM polyphenols significantly suppressed the phosphorylation of JNK, p38, and ERK in a dose-dependent manner in the current study.
These findings confirm the anti-inflammatory effects of SM polyphenols, which may be accomplished by regulating the activation of $\mathrm{NF}-\kappa \mathrm{B}$ and MAPKs signaling pathways. Therefore, SM polyphenols have great potential to be developed into a therapeutic drug for inflammatory-related disorders. In the future, we may also perform animal experiment to further validate our findings. The present study proposed that SM could be effective for treating chronic inflammatory related diseases, including diabetes, cancer and arthritis due to its significant effects on the suppression of the inflammatory response.

\section{Acknowledgements}

Not applicable.

\section{Funding}

The present study was supported partly by the National Research Foundation of Korea (NRF) funded by the Ministry of Science, ICT and Future Planning (grant nos. 2012M3A9B8019303 and 2017R1A2B4003974).

\section{Availability of data and materials}

All data generated or analyzed during this study are included in this published article.

\section{Authors' contributions}

SMK and SJL conceived and designed the experiments, performed the experiments, organized focus group discussion, collected, analyzed all study data; VVGS made contributions to the analysis of data and prepared the final manuscript; SEH and PV revised the study design and prepared the final manuscript; KTD and SCS performed the extraction of polyphenols. JYC, WSL and GSK and revised the study design, revised the results and final revision of manuscript for publication.

\section{Ethics approval and consent to participate}

Not applicable.

\section{Patient consent for publication}

Not applicable.

\section{Competing interests}

The authors declare that they have no competing interests.

\section{References}

1. Torrell M, Cerbah M, Siljak-Yakovlev S and Vallès J: Molecular cytogenetics of the genus Artemisia (Asteraceae, Anthemideae): Fluorochrome banding and fluorescence in situ hybridization. I. Subgenus Seriphidium and related taxa. Plant Syst Evol 239: 141-153, 2003.

2. Lee MY, Doh EJ, Park CH, Kim YH, Kim ES, Ko BS and Oh SE: Development of SCAR marker for discrimination of Artemisia princeps and A. argyi from other Artemisia herbs. Biol Pharm Bull 29: 629-633, 2006. 
3. Shin NR, Ryu HW, Ko JW, Park SH, Yuk HJ, Kim HJ, Kim JC, Jeong SH and Shin IS: Artemisia argyi attenuates airway inflammation in ovalbumin-induced asthmatic animals. J Ethnopharmacol 209: 108-115, 2017.

4. Adams JD, Garcia C and Garg G: Mugwort (Artemisia vulgaris, Artemisia douglasiana, Artemisia argyi) in the treatment of menopause, premenstrual syndrome, dysmenorrhea and attention deficit hyperactivity disorder. Chin Med 3: 116-123, 2012.

5. Ferreira JF, Luthria DL, Sasaki T and Heyerick A: Flavonoids from Artemisia annua L. as antioxidants and their potential synergism with artemisinin against malaria and cancer. Molecules 15: 3135-3170, 2010

6. Adams M, Efferth T and Bauer R: Activity-guided isolation of scopoletin and isoscopoletin, the inhibitory active principles towards CCRF-CEM leukaemia cells and multi-drug resistant CEM/ADR5000 cells, from Artemisia argyi. Planta Med 72: 862-864, 2006

7. Seo JM, Kang HM, Son KH, Kim JH, Lee CW, Kim HM, Chang SI and Kwon BM: Antitumor activity of flavones isolated from Artemisia argyi. Planta Med 69: 218-222, 2003.

8. Kim JH, Kim HK, Jeon SB, Son KH, Kim EH, Kang SK, Sung ND and Kwon BM: New sesquiterpene-monoterpene lactone, artemisolide, isolated from Artemisia argyi. Tetrahedron Lett 43: 6205-6208, 2002

9. Yun C, Jung Y, Chun W, Yang B, Ryu J, Lim C, Kim JH, Kim H and Cho SI: Anti-inflammatory effects of artemisia leaf extract in mice with contact dermatitis in vitro and in vivo. Mediators Inflamm 2016: 8027537, 2016.

10. Yoon KD, Chin YW, Yang MH and Kim J: Separation of anti-ulcer flavonoids from Artemisia extracts by high-speed countercurrent chromatography. Food Chem 129: 679-683, 2011.

11. Ji HY, Kim SY, Kim DK, Jeong JH and Lee HS: Effects of eupatilin and jaceosidin on cytochrome p450 enzyme activities in human liver microsomes. Molecules 15: 6466-6475, 2010.

12. Kim JK, Shin EC, Lim HJ, Choi SJ, Kim CR, Suh SH, Kim CJ, Park GG, Park CS, Kim HK, et al: Characterization of nutritional composition, antioxidative capacity, and sensory attributes of seomae mugwort, a native Korean variety of artemisia argyi $\mathrm{H}$. Lév. \& Vaniot. J Anal Methods Chem 2015: 916346, 2015.

13. Bao X, Yuan H, Wang C, Liu J and Lan M: Antitumor and immunomodulatory activities of a polysaccharide from Artemisia argyi. Carbohydr Polym 98: 1236-1243, 2013.

14. Libro R, Giacoppo S, Soundara Rajan T, Bramanti P and Mazzon E: Natural phytochemicals in the treatment and prevention of dementia: An overview. Molecules 21: 518, 2016

15. Seo ON, Kim GS, Park S, Lee JH, Kim YH, Lee WS, Lee SJ, Kim CY, Jin JS, Choi SK and Shin SC: Determination of polyphenol components of Lonicera japonica Thunb. using liquid chromatography-tandem mass spectrometry: Contribution to the overall antioxidant activity. Food Chem 134: 572-577, 2012.

16. Lee CY: Challenges in providing credible scientific evidence of health benefits of dietary polyphenols. J Funct Foods 5: 524-526, 2013.

17. Carvalho IS, Cavaco T and Brodelius M: Phenolic composition and antioxidant capacity of six artemisia species. Industr Crops Prod 33: 382-388, 2011.

18. Chen L, Deng H, Cui H, Fang J, Zuo Z, Deng J, Li Y, Wang X and Zhao L: Inflammatory responses and inflammation-associated diseases in organs. Oncotarget 9: 7204-7218, 2018.

19. Hayes JB, Sircy LM, Heusinkveld LE, Ding W, Leander RN, McClelland EE and Nelson DE: Modulation of macrophage inflammatory nuclear factor $\kappa \mathrm{B}(\mathrm{NF}-\kappa \mathrm{B})$ signaling by intracellular cryptococcus neoformans. J Biol Chem 291: 15614-15627, 2016.

20. Mittal M, Siddiqui MR, Tran K, Reddy SP and Malik AB Reactive oxygen species in inflammation and tissue injury. Antioxid Redox Signal 20: 1126-1167, 2014.

21. Niu N, Li B, Hu Y, Li X, Li J and Zhang H: Protective effects of scoparone against lipopolysaccharide-induced acute lung injury. Int Immunopharmacol 23: 127-133, 2014.

22. Li P, Zheng Y and Chen X: Drugs for autoimmune inflammatory diseases: From small molecule compounds to anti-TNF biologics. Front Pharmacol 8: 460, 2017.

23. Wang Y, Lai L, Teng L, Li Y, Cheng J, Chen J and Deng C: Mechanism of the anti-inflammatory activity by a polysaccharide from Dictyophora indusiata in lipopolysaccharide-stimulated macrophages. Int J Biol Macromol 126: 1158-1166, 2019.

24. Gautam R and Jachak SM: Recent developments in anti-inflammatory natural products. Med Res Rev 29: 767-820, 2009.
25. Lin D, Xiao M, Zhao J, Li Z, Xing B, Li X, Kong M, Li L, Zhang Q, Liu Y, et al: An overview of plant phenolic compounds and their importance in human nutrition and management of type 2 diabetes. Molecules 21, 2016.

26. Giugliano D, Ceriello A and Esposito K: The effects of diet on inflammation: Emphasis on the metabolic syndrome. J Am Coll Cardiol 48: 677-685, 2006.

27. Ha GJ, Lee DS, Seung TW, Park CH, Park SK, Jin DE, Kim NK, Shin HY and Heo HJ: Anti-amnesic and neuroprotective effects of Artemisia argyi H. (Seomae mugwort) extracts. Korean J Food Sci Technol 47: 380-387, 2015

28. Chen LL, Zhang HJ, Chao J and Liu JF: Essential oil of Artemisia argyi suppresses inflammatory responses by inhibiting JAK/STATs activation. J Ethnopharmacol 204: 107-117, 2017.

29. Song Y, Desta KT, Kim GS, Lee SJ, Lee WS, Kim YH, Jin JS, Abd El-Aty AM, Shin HC, Shim JH and Shin SC: Polyphenolic profile and antioxidant effects of various parts of Artemisia annua L. Biomed Chromatogr 30: 588-595, 2016.

30. Ji G, Zhang Y, Yang Q, Cheng S, Hao J, Zhao X and Jiang Z: Genistein suppresses LPS-induced inflammatory response through inhibiting NF- $\kappa$ B following AMP kinase activation in RAW 264.7 macrophages. PLoS One 7: e53101, 2012.

31. Oh YC, Jeong YH, Cho WK, Ha JH, Gu MJ and Ma JY: Anti-inflammatory and analgesic effects of pyeongwisan on LPS-stimulated murine macrophages and mouse models of acetic acid-induced writhing response and xylene-induced ear edema. Int J Mol Sci 16: 1232-1251, 2015

32. Scarfi S, Magnone M, Ferraris C, Pozzolini M, Benvenuto F, Benatti U and Giovine M: Ascorbic acid pre-treated quartz stimulates TNF-alpha release in RAW 264.7 murine macrophages through ROS production and membrane lipid peroxidation. Respir Res 10: 25, 2009.

33. Han B, Xin Z, Ma S, Liu W, Zhang B, Ran L, Yi L and Ren D: Comprehensive characterization and identification of antioxidants in Folium Artemisiae Argyi using high-resolution tandem mass spectrometry. J Chromatogr B Analyt Technol Biomed Life Sci 1063: 84-92, 2017.

34. Fischer UA, Jaksch AV, Carle R and Kammerer DR: Determination of lignans in edible and nonedible parts of pomegranate (Punica granatum L.) and products derived therefrom, particularly focusing on the quantitation of isolariciresinol using HPLC-DAD-ESI/MSn. J Agric Food Chem 60: 283-292, 2012

35. Yao H, Chen B, Zhang Y, Ou H, Li Y, Li S, Shi P and Lin X: Analysis of the total biflavonoids extract from selaginella doederleinii by HPLC-QTOF-MS and its in vitro and in vivo anticancer effects. Molecules 22, 2017.

36. Zhang YX, Li QY, Yan LL and Shi Y: Structural characterization and identification of biflavones in Selaginella tamariscina by liquid chromatography-diode-array detection/electrospray ionization tandem mass spectrometry. Rapid Commun Mass Spectrom 25: 2173-2186, 2011

37. Pandey R, Chandra P, Arya KR and Kumar B: Development and validation of an ultra high performance liquid chromatography electrospray ionization tandem mass spectrometry method for the simultaneous determination of selected flavonoids in Ginkgo biloba. J Sep Sci 37: 3610-3618, 2014.

38. Kajdžanoska M, Gjamovski $V$ and Stefova $M$ : HPLC-DAD-ESI-MSn identification of phenolic compounds in cultivated strawberries from Macedonia. Macedonian J Chem Chem Eng 29, 2010.

39. Bertrams J, Kunz N, Müller M, Kammerer D and Stintzing FC: Phenolic compounds as marker compounds for botanical origin determination of German propolis samples based on TLC and TLC-MS. J Appl Bot Food Qual 86: 143-153, 2013.

40. Luo JL, Lu FL, Liu YC and Lo CF: Identification of scutellaria baicalensis in traditional Chinese medicine preparations by LC/MS/MS fingerprinting method. J Food Drug Anal 20: $887-899,984,2012$

41. Sanz M, de Simón BF, Cadahía E, Esteruelas E, Muñoz AM, Hernández T, Estrella I and Pinto E: LC-DAD/ESI-MS/MS study of phenolic compounds in ash (Fraxinus excelsior L. and F. americana L.) heartwood. Effect of toasting intensity at cooperage. J Mass Spectrom 47: 905-918, 2012.

42. Miyamae Y, Kurisu M, Han J, Isoda $H$ and Shigemori H: Structure-activity relationship of caffeoylquinic acids on the accelerating activity on ATP production. Chem Pharm Bull (Tokyo) 59: 502-507, 2011. 
43. Green SJ, Scheller LF, Marletta MA, Seguin MC, Klotz FW, Slayter M, Nelson BJ and Nacy CA: Nitric oxide: Cytokine-regulation of nitric oxide in host resistance to intracellular pathogens. Immunol Lett 43: 87-94, 1994.

44. Guzik TJ, Korbut R and Adamek-Guzik T: Nitric oxide and superoxide in inflammation and immune regulation. J Physiol Pharmacol 54: 469-487, 2003.

45. Wu C, Zhao W, Zhang X and Chen X: Neocryptotanshinone inhibits lipopolysaccharide-induced inflammation in RAW264.7 macrophages by suppression of NF- $\mathrm{KB}$ and iNOS signaling pathways. Acta Pharm Sin B 5: 323-329, 2015.

46. Lee JA, Song HY, Ju SM, Lee SJ, Kwon HJ, Eum WS, Jang SH, Choi SY and Park JS: Differential regulation of inducible nitric oxide synthase and cyclooxygenase-2 expression by superoxide dismutase in lipopolysaccharide stimulated RAW 264.7 cells. Exp Mol Med 41: 629-637, 2009.

47. Lawrence T, Willoughby DA and Gilroy DW: Anti-inflammatory lipid mediators and insights into the resolution of inflammation. Nat Rev Immunol 2: 787-795, 2002.

48. Coussens LM and Werb Z: Inflammation and cancer. Nature 420 860-867, 2002

49. Galli SJ, Tsai M and Piliponsky AM: The development of allergic inflammation. Nature 454: 445-454, 2008.

50. Lee JH, Cho DH and Park HJ: IL-18 and cutaneous inflammatory diseases. Int J Mol Sci 16: 29357-29369, 2015.

51. Guha M and Mackman N: LPS induction of gene expression in human monocytes. Cell Signal 13: 85-94, 2001.

52. Yang Y, Kim SC, Yu T, Yi YS, Rhee MH, Sung GH, Yoo BC and Cho JY: Functional roles of p38 mitogen-activated protein kinase in macrophage-mediated inflammatory responses. Mediators Inflamm 2014: 352371, 2014.
53. Dou J, Lee VS, Tzen JT and Lee MR: Identification and comparison of phenolic compounds in the preparation of oolong tea manufactured by semifermentation and drying processes. J Agric Food Chem 55: 7462-7468, 2007.

54. Del Rio D, Stewart AJ, Mullen W, Burns J, Lean ME, Brighenti F and Crozier A: HPLC-MSn analysis of phenolic compounds and purine alkaloids in green and black tea. J Agric Food Chem 52: 2807-2815, 2004.

55. Simirgiotis MJ, Schmeda-Hirschmann G, Bórquez J and Kennelly EJ: The Passiflora tripartita (Banana Passion) fruit: A source of bioactive flavonoid C-glycosides isolated by HSCCC and characterized by HPLC-DAD-ESI/MS/MS. Molecules 18: 1672-1692, 2013

56. Ahmed H, Moawad A, Owis A, AbouZid S and Ahmed O: Flavonoids of Calligonum polygonoides and their cytotoxicity. Pharm Biol 54: 2119-2126, 2016.

57. Bastos DH, Saldanha LA, Catharino RR, Sawaya AC, Cunha IB, Carvalho PO and Eberlin MN: Phenolic antioxidants identified by ESI-MS from Yerba maté (Ilex paraguariensis) and green tea (Camelia sinensis) extracts. Molecules 12: 423-432, 2007.

58. Gouveia S and Castilho PC: Helichrysum monizii Lowe: Phenolic composition and antioxidant potential. Phytochem Anal 23: 72-83, 2012

59. Li W, Pang X, Han LF, Zhou Y and Cui YM: Chemcial constituents of Eclipta prostrata. Zhongguo Zhong Yao Za Zhi 43 3498-3505, 2018 (In Chinese).

This work is licensed under a Creative Commons Attribution-NonCommercial-NoDerivatives 4.0 International (CC BY-NC-ND 4.0) License. 